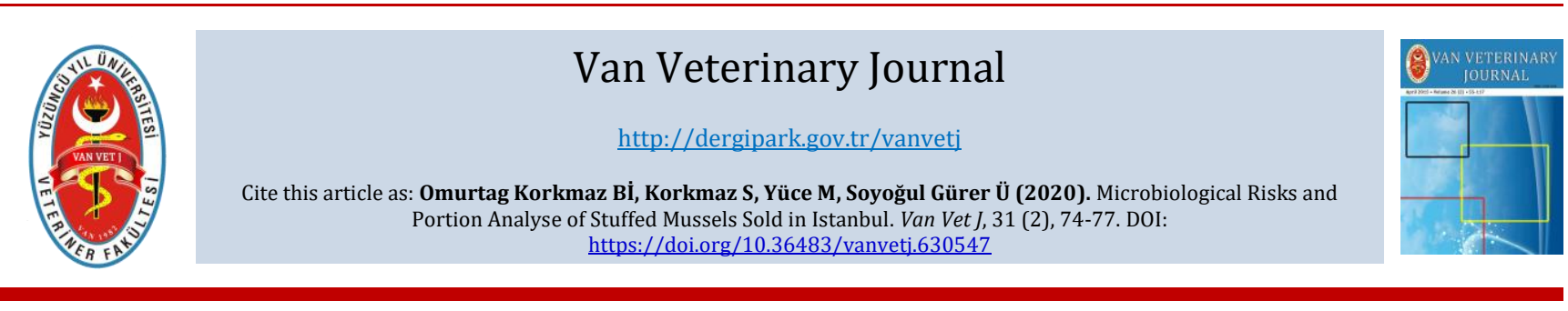

\title{
Microbiological Risks and Portion Analyse of Stuffed Mussels Sold in Istanbul
}

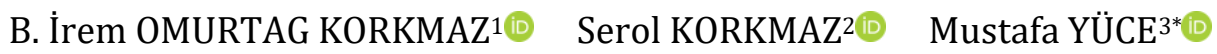 \\ Ümran SOYOĞUL GÜRER ${ }^{4}$ (D)
}

\begin{abstract}
${ }^{1}$ Marmara University, Faculty of Health Science, Department of Nutrition and Dietetics, İstanbul, Turkey ${ }_{2}^{2}$ Pendik Veterinary Control Institute, Ministry of Agriculture and Forest, İstanbul, Turkey

${ }^{3}$ Mardin Artuklu University, Faculty of Health Science, Department of Nutrition and Dietetics, Mardin, Turkey

${ }^{4}$ Marmara University, Faculty of Pharmacy, Department of Pharmaceutical Microbiology, Istanbul, Turkey
\end{abstract}

ABSTRACT In this study, stuffed mussels were collected from 50 selling points in Istanbul, consist of street vendors $(\mathrm{n}=38)$ and retail shops $(\mathrm{n}=12)$, analyzed microbiologically and weighted per portion. Mean Total Aerobic Count result was $7.38 \pm 1.01 \log 10 \mathrm{cfu} / \mathrm{g}$ among the samples. Coliform was isolated from $44 \%$ of samples $(2.85 \pm 0.57 \mathrm{log} \mathrm{cfu} / \mathrm{g})$, Escherichia coli from $12 \%$ of samples $(3.76 \pm 0.71 \mathrm{log} \mathrm{cfu} / \mathrm{g})$, Staphylococcus aureus from $4 \%$ (4.15 $\pm 0.30 \mathrm{log} \mathrm{cfu} / \mathrm{g})$, Bacillus cereus in $2 \%$ (2.78 $\mathrm{log} \mathrm{cfu} / \mathrm{g})$ and Bacillus licheniformis in $4 \%(3.18 \pm 0.08$ $\log \mathrm{cfu} / \mathrm{g}$ ) of samples. Listeria ivanovii was isolated from $2 \%$ of samples (in $25 \mathrm{~g}$ ). No Clostridium spp., Campylobacter spp., Salmonella spp. and Listeria monocytogenes were detected. Level of Staphylococcus spp. (S. aureus + S. epidermidis) contamination was significantly higher in the retail shop $(\mathrm{P}<0.05)$. The mean portion per stuffed mussel was $16.78 \pm 5.62$ g. Except for the result of Staphylococcus spp., microbiological analyses and a gram of portions did not show a significant difference between retail shops and street vendors $(\mathrm{P}>0.05)$. However, an inappropriate level of $S$. aureus contamination in retail shops remain a food safety gap. Furthermore, the mean results of portions are assumed to be used in predictive microbiology studies.

Keywords: Food Safety, Food Microbiology, Mussels

\section{İstanbul'da Satılan Midye Dolmalardaki Mikrobiyolojik Riskler ve Porsiyon Analizi}

Bu çalışmada İstanbul'da sokakta $(n=38)$ ve kapalı restoranda $(n=12)$ satışa sunulan toplam 50 farklı noktadan midye dolma örneği toplanarak mikrobiyolojik inceleme ve porsiyon analizi yapılmıştır. Örneklerin Toplam Aerobik Bakteri sayısı ortalama $7.38 \pm 1.01 \log _{10} \mathrm{kob} / \mathrm{g}$ olarak bulunmuştur. Coliform grubu \%44 (2.85 $\pm 0.57 \mathrm{log} \mathrm{kob} / \mathrm{g})$, Escherichia coli $\% 12$ (3.76 $\pm 0.71 \mathrm{log} \mathrm{kob} / \mathrm{g})$, Staphylococcus aureus \%4 (4.15 $\pm 0.30 \mathrm{log}$ $\mathrm{kob} / \mathrm{g}$ ), Bacillus cereus \%2 (2.78 log cfu/g) ve Bacillus licheniformis \%4 (3.18 $\pm 0.08 \mathrm{log} \mathrm{cfu} / \mathrm{g}$ ) oranında izole edilmiştir. Listeria ivanovii \%2 oranında tespit edilmiștir. Clostridium spp., Campylobacter spp., Salmonella spp. ve Listeria monocytogenes tespit edilmemiştir. Staphylococcus spp. (S. aureus + S. epidermidis) kontaminasyon düzeyi restoranlarda anlamlı olarak daha yüksek bulunmuştur $(P<0.05)$. Midye dolmaların adet porsiyonu ortalama $16.78 \pm 5.62$ g olarak tartılmıştır. Staphylococcus spp. sonuçları dışında mikrobiyolojik analizler ve porsiyon gramajları restoranlar ile sokak satış noktaları arasında anlamlı bir fark göstermemiştir $(P>0.05)$. Ancak S.aureus'un kapalı restoranlarda tüketim için uygun düzeyin üzerinde tespit edilmesi bir gıda güvenliği açığının bulunduğuna işaret etmektedir. Porsiyon ortalamalarının ileride prediktif mikrobiyoloji çalışmalarında kullanılabileceği öngörülmektedir.

Anahtar Kelimeler: Gıda Güvenliği, Gıda Mikrobiyolojisi, Midye

\section{INTRODUCTION}

Stuffed mussel is one of the most popular street food consumed in Istanbul, Turkey (Güzeler and Özbek 2017). It is mostly sold by street vendors and available in retail shops (Kisla and Uzgun 2008). In most case, unemployed immigrants collectively help for the preparation of stuffed mussel and sell on the streets (Eranil Demirli et al. 2015). Thus, in retail shops is the expected health risk is low, however unregulated street vendors bear the risk of illness.

Several foodborne bacterial pathogens, such as E. coli, $B$. cereus, S. aureus, Salmonella spp. and C. perfringens and 
also viruses were isolated from stuffed mussels in former studies (Bingöl et al. 2008; Ateş et al. 2011). High frequency of Coliform and different amount of B. cereus, $S$. aureus and Vibrio spp. were detected in stuffed mussels collected from street vendors of Turkey (Ergönül et al. 2014). According to the microbiological results of Bingöl et al. (2008), 18.4\% of stuffed mussels sold in Istanbul were contaminated in an unacceptable limit of consumption. Additionally, related to the consumption of stuffed mussels a life-threatening case has been also reported in Turkey (Urazel et al. 2014).

Stuffed mussel is particularly consumed in high demand areas of Istanbul. Most of the sellers prefer to calculate the portion according to the number of consumed stuffed mussels. However, consumed portion, i.e. the amount of rice and mussel, varies by the consumer's preference. However, there is lack of information in the literature on the average grammage of the edible portion of stuffed mussel, which can be useful for studies on the risk/benefit assessment not only microbial but also chemical contaminants and dietary value of this food item.

Hence, in this study stuffed mussels sold in street vendors and retail shops (restaurants) in major places in Istanbul were selected for investigation. Ready-to-eat stuffed mussels were collected from 50 different selling points and analyzed microbiologically. Regard to the amount of edible portion per stuffed mussel, the results of this study is assumed to be used for future predictive microbiology and dietary studies.

\section{MATERIALS and METHODS}

\section{Sampling plan}

Stuffed mussels were collected from 50 different locations (10 samples from each) including 38 street vendors and 12 retail shops in Istanbul. Sampling was performed with the assumption of increased temperature and decreased hygienic quality (related to the high temperature) in the summer month (June 2016). All the samples were transported to the laboratory in a refrigerated box and immediately analyzed.

\section{Microbiological analyses}

Edible components were weighed and $25 \mathrm{~g}$ of each sample was transferred to Stomacher filter bags and $225 \mathrm{ml}$ of enrichment solutions were added (1:10 ratio). Afterward, samples were homogenized in Stomacher bags and tenfold serial dilution was prepared with Maximum Recovery Diluent (Oxoid CM0733). Appropriate dilutions were spread onto Total Aerobic Count (TAC) and selective agar plates for enumeration. The name of the bacteria investigated and media used in the isolations are shown in Table 1.

\section{Edible portion weights}

Three samples from each selling point were weighted without shell (only mussel meat and rice components). Mean results of grammage were calculated and compared between street vendors and restaurants.

\section{Data analyses}

Results of microbiological analyses transformed to $\log 10$ unit by using MS Excel and all counts were analyzed statistically with SPSS (version 11.5). A possible relationship between the microflora and weight results was observed for street vendors and retail shops according to t-test and one-way Anova test. $P<0.05$ was considered statistically significant.
Table 1. Isolation and identification procedures of the investigated bacteria

\begin{tabular}{|c|c|c|c|}
\hline $\begin{array}{l}\text { Investig. } \\
\text { bacteria }\end{array}$ & Media & Incuba. & Reference \\
\hline TAC & $\begin{array}{l}\text { Plate Count Agar } \\
\text { (Oxoid CM0325) }\end{array}$ & $30^{\circ} \mathrm{C}, 48 \mathrm{~h}$ & (ISO 2003) \\
\hline E.coli & $\begin{array}{l}\text { Coli ID agar } \\
\text { (BioMeriéux 42017) }\end{array}$ & $42^{\circ} \mathrm{C}, 24 \mathrm{~h}$ & $\begin{array}{l}\text { (Omurtag } \\
\text { et al. } \\
2012)\end{array}$ \\
\hline Coliform & $\begin{array}{l}\text { Coli ID agar } \\
\text { (BioMeriéux 42017) }\end{array}$ & $42^{\circ} \mathrm{C}, 24 \mathrm{~h}$ & $\begin{array}{l}\text { (Omurtag } \\
\text { et al. } \\
2012)\end{array}$ \\
\hline \multirow[t]{2}{*}{$\begin{array}{l}\text { Staphyloco } \\
\text { ccus spp. }\end{array}$} & $\begin{array}{l}\text { Baird-Parker Agar } \\
\text { (Merck Nr.1.05406) } \\
\text { with egg yolk } \\
\text { (Merck Nr.1.03784) }\end{array}$ & \multirow[t]{2}{*}{$37^{\circ} \mathrm{C}, 48 \mathrm{~h}$} & \multirow[t]{2}{*}{$\begin{array}{l}\text { (Omurtag } \\
\text { et al. } \\
2012)\end{array}$} \\
\hline & $\begin{array}{l}\text { ID } 32 \quad \text { STAPH } \\
\text { (BioMeriéux) }\end{array}$ & & \\
\hline \multirow[t]{2}{*}{$\begin{array}{l}\text { Bacillus } \\
\text { cereus }\end{array}$} & $\begin{array}{ll}\text { BACARA } & \text { agar } \\
\text { (BioMeriéux) } & \end{array}$ & \multirow[t]{2}{*}{$37^{\circ} \mathrm{C}, 24 \mathrm{~h}$} & \multirow{2}{*}{$\begin{array}{l}\text { (Thepaut } \\
\text { and } \\
\text { Soriano } \\
\text { 2012, } \\
\text { Tallent et } \\
\text { al. 2012) }\end{array}$} \\
\hline & $\begin{array}{l}\text { API } 50 \quad \text { CHB/E } \\
\text { (Biomerieux) }\end{array}$ & & \\
\hline \multirow[t]{4}{*}{$\begin{array}{l}\text { Salmonella } \\
\text { spp. }\end{array}$} & $\begin{array}{lr}\text { Buffered } & \text { Peptone } \\
\text { Water } & \text { (Oxoid } \\
\text { CM0509) } & \end{array}$ & \multirow[t]{2}{*}{$\begin{array}{l}37^{\circ} \mathrm{C}, 24 \mathrm{~h} \\
42^{\circ} \mathrm{C}, 24 \mathrm{~h}\end{array}$} & \multirow[t]{4}{*}{$\begin{array}{l}\text { (Omurtag } \\
\text { et al. } \\
2012)\end{array}$} \\
\hline & $\begin{array}{l}\text { MSRV motility agar } \\
\text { (Oxoid CM0910) }\end{array}$ & & \\
\hline & $\begin{array}{ll}\text { XLD-agar } & \text { (Merck } \\
\text { Nr.1.05287) }\end{array}$ & \multirow{2}{*}{$37^{\circ} \mathrm{C}, 24 \mathrm{~h}$} & \\
\hline & $\begin{array}{lcc}\text { API } & 20 & \text { E } \\
\text { (BioMeriéux) } & \end{array}$ & & \\
\hline \multirow[t]{2}{*}{$\begin{array}{l}\text { Clostridium } \\
\text { spp. }\end{array}$} & $\begin{array}{l}\text { TSC agar (Merck Nr. } \\
111972 \text { ) }\end{array}$ & \multirow{2}{*}{$\begin{array}{l}37^{\circ} \mathrm{C}, 24 \mathrm{~h} \\
\text { anaerobica } \\
\text { lly }\end{array}$} & \multirow{2}{*}{$\begin{array}{l}\text { (Rhodeha } \\
\text { mel and } \\
\text { Harmon } \\
\text { 2001) }\end{array}$} \\
\hline & $\begin{array}{l}\text { API } 20 \text { A, rapid ID } \\
32 \mathrm{~A}\end{array}$ & & \\
\hline \multirow[t]{3}{*}{$\begin{array}{l}\text { Listeria } \\
\text { spp. }\end{array}$} & $\begin{array}{l}\text { Fraser Broth [Fraser } \\
\text { Broth Base (Oxoid } \\
\text { CM0895) Fraser } \\
\text { Listeria selective } \\
\text { supplement (Merck } \\
\text { Nr.1.00093), } \\
\text { Ammonium- } \\
\text { ferric(III)-citrate } \\
\text { (Merck 3762) }\end{array}$ & \multirow[t]{3}{*}{$37^{\circ} \mathrm{C}, 37 \mathrm{~h}$} & \multirow[t]{3}{*}{$\begin{array}{l}\text { (Omurtag } \\
\text { et al. } \\
2012)\end{array}$} \\
\hline & $\begin{array}{ll}\text { ALOA } & \text { Agar } \\
\text { (BioMeriéux) } & \end{array}$ & & \\
\hline & $\begin{array}{l}\text { API Listeria } \\
\text { (BioMeriéux) }\end{array}$ & & \\
\hline \multirow[t]{3}{*}{$\begin{array}{l}\text { Campyloba } \\
\text { cter spp. }\end{array}$} & $\begin{array}{lr}\text { Bolton Broth } & \text { (Oxoid } \\
\text { CM0983, } & \text { with } \\
\text { supplement } & \text { Oxoid } \\
\text { SR0208E) } & \end{array}$ & \multirow[t]{3}{*}{$\begin{array}{l}42^{\circ} \mathrm{C}, 48 \mathrm{~h}, \\
\text { microaero } \\
\text { bically }\end{array}$} & \multirow[t]{3}{*}{$\begin{array}{l}\text { (Omurtag } \\
\text { et al. } \\
2012)\end{array}$} \\
\hline & $\begin{array}{lr}\text { m-CCDA } & \text { (Oxoid } \\
\text { CM0739, } & \text { with } \\
\text { supplement } & \text { Oxoid } \\
\text { SR0155E) } & \end{array}$ & & \\
\hline & $\begin{array}{l}\text { API CAMPY } \\
\text { (Biomerieux) }\end{array}$ & & \\
\hline
\end{tabular}




\section{RESULTS}

Among 50 selling points, TAC levels of samples ranged from 4.31 to $8.60 \log 10 \mathrm{cfu} / \mathrm{g}$, with a mean of $7.38 \pm 1.01$ $\log \mathrm{cfu} / \mathrm{g}$. TAC levels did not show a significant difference between street vendors and retail shops. Almost half of the samples were contaminated with Coliform (44\%), whereas Escherichia coli (12\%) was most frequently isolated pathogen, which from this follows Staphylococcus aureus (4\%) and Bacillus cereus (2\%). Except for one stuffed mussel, most of the samples contaminated with E.coli did not contain Coliform, which is usually associated with the poor hygienic condition. One sample was contaminated with Listeria ivanovii (2\%), and two samples with Bacillus licheniformis (4\%). All of the results of microbiological analyses were presented in Table 2 .

Table 2. Comparison of microbiological analyses (mean $\log 10 \mathrm{cfu} / \mathrm{g}$ ) and portion results of stuffed mussels according to the selling point $(\mathrm{n}=50)$

\begin{tabular}{|c|c|c|c|c|c|c|c|c|c|c|c|c|c|c|c|c|}
\hline & $\begin{array}{l}\text { TAC } \\
(n=50)\end{array}$ & & $\begin{array}{l}\text { E.coli } \\
(\mathrm{n}=6)\end{array}$ & & $\begin{array}{l}\text { Coliform } \\
(n=22)\end{array}$ & & $\begin{array}{l}\text { S. aureus } \\
(\mathrm{n}=2)\end{array}$ & & $\begin{array}{l}S . \\
\text { epidern } \\
(\mathrm{n}=1)\end{array}$ & idis & $\begin{array}{l}\text { Bacillus } \\
\text { cereus } \\
(n=1)\end{array}$ & & $\begin{array}{l}\text { Bacillus } \\
\text { licheniform } \\
\text { is } \\
(\mathrm{n}=2)\end{array}$ & $\begin{array}{l}\text { Liste } \\
\text { ivan } \\
(\mathrm{n}=1\end{array}$ & $\begin{array}{l}i a \\
\text { vii* }\end{array}$ & $\begin{array}{l}\text { Weight } \\
\text { of } \\
\text { edible } \\
\text { compon } \\
\text { ent }\end{array}$ \\
\hline $\begin{array}{l}\text { Selling } \\
\text { point }\end{array}$ & mean & $\%$ & mean & $\%$ & mean & $\%$ & mean & $\%$ & mean & $\%$ & mean & $\%$ & mean & $+/-$ & $\%$ & $\begin{array}{l}\mathrm{g} \\
\text { stuffed } \\
\text { mussel }\end{array}$ \\
\hline $\begin{array}{l}\text { Street } \\
\text { vendor } \\
(n=38)\end{array}$ & $\begin{array}{l}7.37 \quad \pm \\
0.98\end{array}$ & 100 & $\begin{array}{l}4.09 \\
\pm \\
0.58 \\
\end{array}$ & 8 & $\begin{array}{l}2.83 \pm \\
0.62\end{array}$ & $\begin{array}{l}1 \\
4\end{array}$ & 2.30 & 2 & - & - & - & - & $\begin{array}{l}3.09 \pm 4 \\
0.12\end{array}$ & + & 2 & $\begin{array}{l}15.63 \pm \\
5.58\end{array}$ \\
\hline $\begin{array}{l}\text { Retail } \\
\text { shop } \\
(n=12)\end{array}$ & $\begin{array}{l}7.39 \\
1.17\end{array}$ & 100 & $\begin{array}{l}3.11 \\
\pm \\
0.47\end{array}$ & 4 & $\begin{array}{l}2.88 \pm \\
0.47\end{array}$ & $\begin{array}{l}3 \\
0\end{array}$ & 6 & 2 & 5.57 & 2 & 2.78 & 2 & - & - & - & $\begin{array}{l}20.40 \pm \\
5.97\end{array}$ \\
\hline Overall & $\begin{array}{l}7.38 \quad \pm \\
1.01\end{array}$ & 100 & $\begin{array}{l}3.76 \\
\pm \\
0.71\end{array}$ & 12 & $\begin{array}{l}2.85 \pm \\
0.57\end{array}$ & $\begin{array}{l}4 \\
4\end{array}$ & $\begin{array}{l}4.15 \quad \pm \\
0.30\end{array}$ & 4 & 5.57 & 2 & 2.78 & 2 & $\begin{array}{l}3.09 \pm 4 \\
0.12\end{array}$ & + & 2 & $\begin{array}{l}16.78 \pm \\
5.62\end{array}$ \\
\hline p-value & 0.96 & & 0.83 & & 0.25 & & $0.019 * *$ & & & & 0.78 & & & - & & 0.336 \\
\hline
\end{tabular}

${ }^{*}$ Listeria spp. was not enumerated, ${ }^{* *}$ Staphylococcus spp. level of contamination was significantly higher in retail shops (P $<0.05$ )

Escherichia coli was twice more frequently isolated in street vendors when compared to retail shops, whereas $S$. aureus contamination in the retail shop was higher than the appropriate level of consumption (6 log kob/g) and this result showed a significant difference from street vendors $(\mathrm{P}<0.05)$. Another toxin-producing bacteria, B.cereus, was obtained only from a retail shop. In this study, Clostridium sp., Salmonella sp., Listeria monocytogenes and Campylobacter spp. were not detected.

The weight of edible portion (rice and mussel meat) of stuffed mussels ranged from $7.68 \mathrm{~g}$ to $32.20 \mathrm{~g}$, with a mean of $16.78 \pm 5.62 \mathrm{~g}$. No significant difference was found in weight of samples between the selling points (Table 2).

\section{DISCUSSION}

As a result of being street food, in this study samples were mostly available in street vendors (38 of 50 selling points). TAC results varied between $4.31 \mathrm{log}$ and $8.60 \mathrm{log} \mathrm{cfu} / \mathrm{g}$ and was certainly higher than the recent studies conducted in Turkey, which varies from $<1 \log$ to $6.44 \mathrm{log} \mathrm{cfu} / \mathrm{g}$ (Ergönül et al. 2014; Kök et al. 2015). Low microbiological quality of water, that mussels were collected from and additionally unhygienic condition during food preparation were suggested as some of the reasons of an unacceptable load of bacterial and viral contamination in stuffed mussel (Yılmaz et al. 2010; Ateş et al. 2011).

Studies conducted on the microbiological safety of this food item sold in Turkey found contamination with several foodborne pathogens, such as; Bacillus cereus, Staphylococcus aureus, Escherichia coli, Salmonella sp., Clostridium perfringens, and Vibrio spp. (Bingöl et al. 2008; Yılmaz et al. 2010; Ateş et al. 2011; Ergönül et al. 2014).
Food inspectors evaluate stuffed mussel in the Food Security Criteria of Turkish Food Codex (TFC) under the ready-to-eat cold snack category (TFC 2011). Therefore, it is limited for E. coli as $101 \mathrm{cfu} / \mathrm{g}$, and required no staphylococcal enterotoxins, Salmonella and Listeria monocytogenes contamination in $25 \mathrm{~g}$ of sample. According to the Production Hygiene Criteria of TFC cooked crustaceans with/without shell (which is a component of stuffed mussel) have limits for E. coli and coagulase-positive staphylococcus as $101(1 \mathrm{log}) \mathrm{cfu} / \mathrm{g}$ and 103 (3 log) cfu/g, respectively (TFC, 2011). In the present study, average E. coli (3.76 log cfu/g) and S. aureus (4.15 $\log \mathrm{cfu} / \mathrm{g}$ ) contamination were above these values, which indicates a requirement of production hygiene improvement. Although there is no limit set for B. cereus within these criteria, its contamination bear risk for food safety, due to its toxin production potential.

Listeria ivanovii is rarely causing illness in human, but still one of the important foodborne pathogens. It is isolated in several studies from stuffed mussels (Kök et al. 2015; Guillet et al. 2010). However, L. monocytogenes was not isolated in most of the studies conducted on stuffed mussels (Terzi et al. 2015; Kök et al. 2015). In this study, $L$. monocytogenes is not isolated either, but L. ivanovii was determined in one sample from a street vendor. As well as other important foodborne pathogens such as Salmonella spp., Campylobacter spp. and Clostridium spp. were not found. Thus, these results are promising when compared with the former studies.

On the other hand, retail shops in this study were more frequently contaminated with coliforms, Staphylococcus spp. and B. cereus. Regard to the significantly higher contamination rate in retail shops (particularly for 
S. aureus) it is assumed that chance of cross-contamination, i.e. contact with other foodstuffs, is more common in retail shops than street vendors. Studies on technological applications in stuffed mussels showed that modified atmosphere packaging extended the shelf-life of stuffed mussels (Ulusoy and Ozden 2011) and lemon juice dressing decreased the level of Salmonella Typhimurium in the stuffed mussel (Kişla 2007). However, bacterial toxins resistant to food processing treatments; e.g. S. aureus enterotoxins and emetic toxin of B. cereus (EFSA 2012) should also be considered as an important hazard for retail shops.

In this study grammages of edible portions had a wide range (from $7.68 \mathrm{~g}$ to $32.20 \mathrm{~g}$ ). This difference might be the result of the type of mussels used for preparation, e.g. some mussel species are smaller and take less amount of rice. Nevertheless, the mean amount of edible portions did not show statistical significance between street vendors $(15.63 \pm 5.58 \mathrm{~g})$ and retail shops $(20.40 \pm 5.97 \mathrm{~g})$. Following this result, as a standardized portion grammage by weighing the food item before selling, can be suggested rather than count per mussel.

In most of the studies, stuffed mussels have a high-level TAC and S. aureus, E. coli, B. cereus, L. ivanovii were most isolated bacteria with different level of contamination. In this study, $S$. aureus contamination in a retail shop exceeded twice more (6 log cfu/g) the accepted limit in TFC $(<3 \log \mathrm{cfu} / \mathrm{g})$. Thus, the high contamination count of TAC and Coliform, and E. coli, when compared with other studies, indicates a low hygienic status in both of the street vendors and retail shops. These results give an overview that L. ivanovii might be evaluated as a normal flora agent or a hygienic indicator of this food item. On the other hand, edible portion size affects the risk of exposure to several contaminants, as well as carry nutritional importance. Therefore it is assumed that the data of edible portion may be useful with additional information like $\mathrm{pH}$ and aw for future predictive microbiology studies.

\section{CONCLUSION}

As a remarkable result of this study, both of $S$. aureus and $B$. cereus were found in samples. Therefore, a possible exposure to these bacteria via consumption of contaminated stuffed mussels can be realized for a further risk assessment research.

\section{CONFLICT of INTEREST}

The authors declare that they have no conflict of interest.

\section{ACKNOWLEDGEMENT}

This study was supported by Marmara University Research Council (BAPKO, SAG-C-YLP-111115-0504). The authors are thankful for the sincere support of Esra Dalkılıç during laboratory analyses. Also, Turkish 12th
Congress of Food was presented as a poster is printed as text summary of the proceedings.

\section{REFERENCES}

Ateş M, Ozkizilcik A, Tabakoglu C (2011). Microbiological analysis of stuffed mussels sold in the streets. Indian J Microbiol, 51, 350-354.

Bingöl B, Çolak H, Hampikyan H, Muratoglu K (2008). The microbiological quality of stuffed mussels (Midye Dolma) sold in Istanbul. $B F J, 110,1079-1087$.

Eranıl Demirli M, Tuna Ultav Z, Demirtaş-Milz N (2015). A socio-spatial analysis of urban transformation at a neighborhood scale: The case of the relocation of Kadifekale inhabitants to TOKİ Uzundere in İzmir. Cities, 48, 140-159.

Ergönül B, Kundakçı A, Durgun S (2014). Hygienic quality of stuffed Mediterranean mussels (Mytilus gallovincialis) sold by Street venders in İzmir, Turkey. J Food Safety Food Qual, 65, 121-124.

European Food Safety Authority (EFSA) (2012). Scientific Opinion on Public health risks represented by certain composite products containing food of animal origin. EFSA J, 10, 2662.

Guillet C, Join-Lambert 0, Le Monnier A et al. (2010). Human Listeriosis caused by Listeria ivanovii. Emerg Infect Dis, 16, 136-138.

Güzeler N, Özbek Ç (2017). Conceptual analysis of street flavors of Turkey. Analele Universităţii din Craiova, seria Agricultură - Montanologie Cadastru (Annals of the University of Craiova - Agriculture Montanology, Cadastre Series) Vol. XLVII.

ISO 6887-6:2013 (2003). Microbiology of food and animal feed -Preparation of test samples, initial suspension and decimal dilutions for microbiological examination -- Part 6: Specific rules for the preparation of samples taken at the primary production stage.

Kişla D (2007). Effectiveness of lemon juice in the elimination of Salmonella Typhimurium in stuffed mussels. J Food Prot, 70, 28472850 .

Kişla D, Uzgun Y (2008). Microbiological evaluation of stuffed mussels. J Food Protect, 7, 616-620.

Kök F, Şahiner C, Koçak P, Göksoy EÖ, Beyaz D, Büyükyörük S (2015). Determination of Microbiological Quality of Stuffed Mussels Sold in Aydin and Izmir. MJEN, 3, 70-76.

Omurtag I, Smulders FJM, Hilbert F, Paulsen P (2012). Microbiological condition of chicken doner kebab sold in Vienna, Austria. Arch Lebensmittelhyg, 63, 142-146.

Rhodehamel EJ, Harmon SM (2001). Clostridium perfringens. In: FDA (Ed.) Bacteriological Analytical Manual, Chapter 12. Silver Spring, Food and Drug Administration.

Tallent SM, Rhodehamel EJ, Harmon SM, Bennett RW (2012). In: FDA (Ed.) Bacteriological Analytical Manual Chapter 14, Bacillus cereus. Food and Drug Administration.

Terzi G, Gücükoğlu A, Çadirci Ö, Uyanik T, Alişarli M (2015). Serotyping and antibiotic susceptibility of Listeria monocytogenes isolated from ready-to-eat foods in Samsun, Turkey. TurkJ Vet Anim Sci, 39, 211-217.

Thepaut J, Soriano H (2012). Comparison of BACARA $®$ agar, a new chromogenic medium and MYP agar for the enumeration of B.cereus in food sample. Aes Chemunex-BioMérieux.

Turkish Food Codex (TFC) (2011). Turkish Food Codex, Regulation of microbiological criteria. Nr. 28157.

Ulusoy S, Ozden 0 (2011). Preservation of stuffed mussels at 4 degrees $C$ in modified atmosphere packaging. J Aquat Food Prod Technol, 20, 319330.

Urazel B, Celikel A, Karbeyaz K, Akkaya H (2014). The evaluation of forensic cases reported due to food poisoning. Dicle Med J, 41, 113-117.

Yllmaz $\mathbf{H}$, Bostan $\mathbf{K}$, Turan $\mathbf{K}$ et al. (2010). RealTime PCR detection of Norovirus in mussels collected from the bosphorus in Istanbul, Turkey. Food Environ Virol, 2, 64-68. 